\section{OMIII}

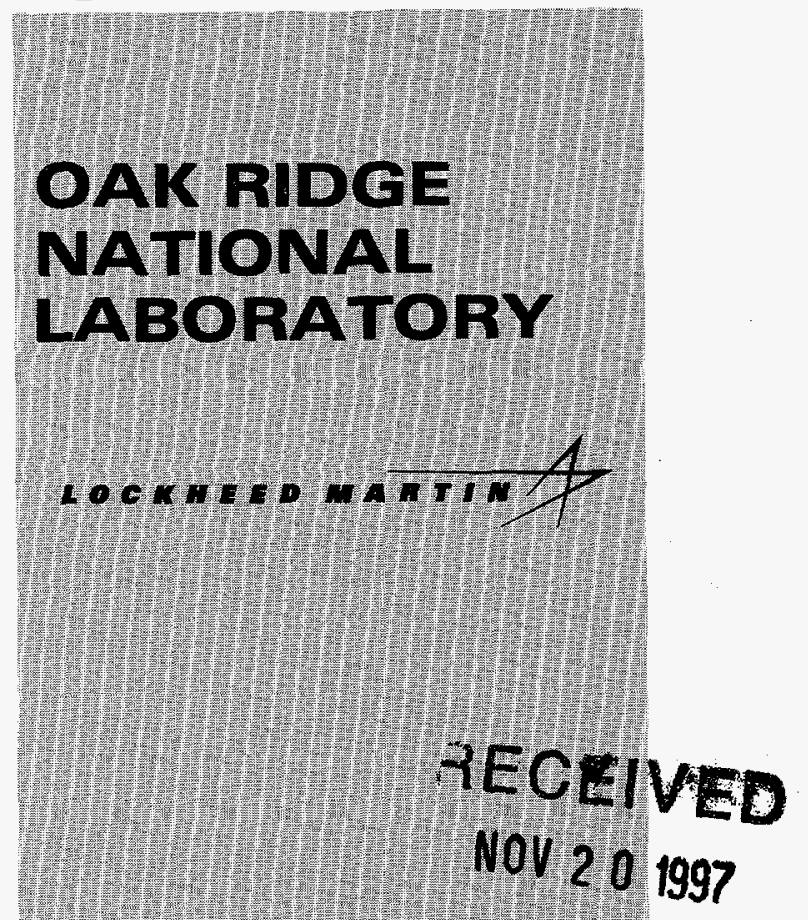

USTI
APPROVED FOR PUBLIC RELEASE

C/ORNL93-0228

\author{
CRADA Final Report \\ for \\ CRADA Number ORNL93-0228
}

\section{GAS PRESSURE SINTERING OF SILICON NITRIDE}

\author{
T. N. Tiegs \\ Oak Ridge National Laboratory \\ L. Leaskey and R. O. Loutfy \\ Materials and Elecrrochemical Research \\ Corporation
}

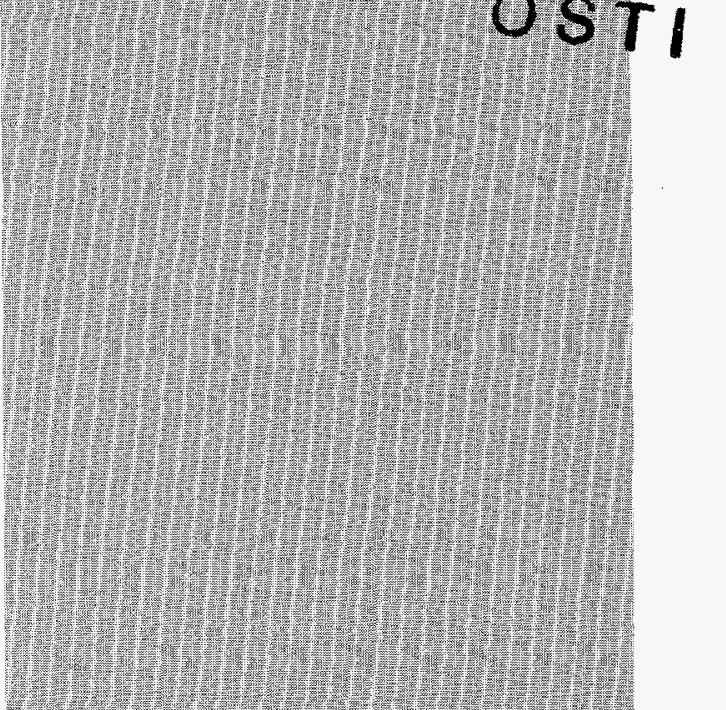

IMNAGED AND OPERATEO BY LOCKREED MARTN ENERGY RESEARCH CORPORATION FOA THE UITED STITES

DEPARTENT OF ENERGY

\author{
Prepared by the \\ Oak Ridge National Laboratory \\ Oak Ridge, Tennessee 37831 \\ managed by \\ Lockheed Martin Energy Research Corporation \\ for the \\ U.S. Department of Energy \\ under contract DE-AC05-960R22464
}

APPROVED FOR PUBLIC RELEASE

UNLIMITED DISTRIBUTION

GISTRIEUTION OF THIS DOCUMENT IS UNLIMITED 
This report has been reproduced directly from the best available copy.

Available to DOE and DOE contractors from the Office of Scientific and Technical Information, P. O. Box 62, Oak Ridge, TN 37831; prices available from (423) 576-8401, FTS 626-8401.

Available to the public from the National Technical Information Service, U.S. Department of Commerce, 5285 Port Royal Road, Springfield, VA 22161.

This report was prepared as an account of work sponsored by an agency of the United States Government. Neither the United States Government nor any agency thereof, nor any of their employees, makes any warranty, express or implied, or assumes any legal liability or responsibility for the accuracy, completeness, or usefulness of any information, apparatus, product, or process disclosed, or represents that its use would not infringe privately owned rights. Reference herein to any specific commercial product, process, or service by trade name, trademark, manufacturer, or otherwise, does not necessarily constitute or imply its endorsement, recommendation, or favoring by the United States Government or any agency thereof. The views and opinions of authors expressed herein do not necessarily state or reflect those of the United States Government of any agency thereof. 


\section{DISCLAMIER}

Portions of this docoment may be illegibie in electronic imsge products. Images are produced from the best available original document 


\author{
CRADA Final Report \\ for \\ CRADA Number ORNL93-0228
}

\title{
GAS PRESSURE SINTERING OF SILICON NITRIDE
}

\author{
T. N. Tiegs \\ Oak Ridge National Laboratory \\ L. Leaskey and R. O. Loutfy \\ Materials and Electrochemical Research Corporation \\ Prepared by the \\ Oak Ridge National laboratory \\ Oak Ridge, Tennessee 37831 \\ managed by \\ Lockheed Martin Energy Research Corporation \\ for the \\ U.S. Department of Energy \\ under contract DE-AC05-960R22464
}

Unlimited Distribution 


\section{CONTENTS}

ABSTRACT

OBJECTIVES AND TASKS

BACKGROUND AND BENEFITS

RESULTS.

SUMMARY

DISTRIBUTION

Research sponsored by the U.S. Department of Energy, Assistant Secretary for Energy Efficiency and Renewable Energy, Office of Transportation Technologies, as part of the Heavy Vehicle Propulsion System Materials Program, under contract DE-AC05960R22464 with Lockheed Martin Energy Research Corporation. 
CRADA NO.: 93-0228 with Materials and Electrochemical Research Corp.

TITLE: GAS PRESURE SINTERING OF SILICON NITRIDE

\section{ABSTRACT}

The Cooperative Research and Development Agreement (CRADA) with Materials and Electrochemical Research Corp. (MER) examined materials made with different starting $\alpha / \mathrm{B}-\mathrm{Si}_{3} \mathrm{~N}_{4}$ ratios and with the addition of sintering aids as coatings instead of powders. The samples were sintered by GPS using optimum densification parameters developed for high toughness materials in the ORNL program.

High densities were achieved for all of the samples fabricated at ORNL and containing up to $50 \% \mathrm{~B}_{-} \mathrm{Si}_{3} \mathrm{~N}_{4}$. The effect of the type of $\mathrm{B}_{-} \mathrm{Si}_{3} \mathrm{~N}_{4}$ seed on flexural strength and fracture toughness indicated seeds fabricated by the reaction of either yttrium nitrate or $\mathrm{Y}_{2} \mathrm{O}_{3}$ powder and Ube E-10 $\mathrm{Si}_{3} \mathrm{~N}_{4}$ developed materials with the highest flexural strength. However, the fracture toughness of these materials (at the 25\% addition level) showed no improvement over the baseline composition having no B-seed addition. The effects of the B-seed content on flexural strength and fracture toughness were mixed. Higher toughnesses were observed with 50\% B-seed additions, while the other additive levels showed no consistent improvements.

\section{OBJECTIVES AND TASKS}

The objectives of the CRADA were to establish:

1. The effect of introducing the sintering additives as a coating compared to conventional powders. The goal was to use less additives and thus enhance high temperature mechanical properties.

2. The effect of using $\mathrm{B}-\mathrm{Si}_{3} \mathrm{~N}_{4}$ seeds to enhance acicular grain growth to achieve high fracture toughness.

The tasks of the CRADA were:

Task 1 - MER would fabricate samples with various starting $\alpha / B-S_{3} \mathrm{~N}_{4}$ ratios. Most of the samples were made with the sintering aids added as coatings. However, for direct comparison, at least one composition with the sintering aids added as powders was made. Approximately 4 samples of 6-8 different compositions were fabricated under this task.

Task 2 - ORNL fabricated samples with either rare earth silicates or rare earth apatites as intergranular phases and having various starting $\alpha / B-\mathrm{Si}_{3} \mathrm{~N}_{4}$ ratios. The sintering aids were added as powders. Approximately 4 samples of 6-8 different compositions were fabricated under this task.

Task 3 - ORNL gas pressure sintered the samples using about four different conditions of time and temperature appropriate to obtain high density parts.

Task 4 - Characterization of the samples was to be split between ORNL and MER. ORNL would determine density of the sintered specimens, perform SEM of selected sintered specimens, measure fracture toughness by indentation/strength techniques, and determine the flexural strength. MER was to determine density of the sintered specimens, perform 
SEM of selected coated $\mathrm{Si}_{3} \mathrm{~N}_{4}$ powders, measure fracture toughness by single edge notch beam techniques, determine the flexural strength at room temperature, and perform $\mathrm{x}$-ray diffraction on selected samples.

\section{BACKGROUND AND BENEFITS}

Significant improvement in the reliability of structural ceramics for advanced engine applications could be achieved if the critical fracture toughness $\left(\mathrm{K}_{\mathrm{Ic}}\right)$ were increased without strength degradation. Silicon nitride ceramics are the leading candidate materials for high temperature structural applications because of their combination of excellent strength, fracture toughness, wear resistance, thermal shock tolerance and high temperature properties. It has been long recognized that silicon nitride obtains its superior properties from the interlocking $\mathrm{B}-\mathrm{Si}_{3} \mathrm{~N}_{4}$ grain structure developed during densification. The growth of these elongated grains can lead to significant improvements in the fracture toughness of the materials.

Microstructural development to promote this type of growth was being examined by ORNL and MER. The ORNL work was being done under the Ceramic Technology for Advanced Heat Engines Project. The MER work was being done as part of a SBIR subcontract from DOD entitled, "Controlled Microstructure Development of Silicon Nitride to Enhance Fracture Toughness." As a small business, MER was able to use the money from the subcontract as their portion of the funds in a CRADA.

ORNL was currently examining gas pressure sintering (GPS) of silicon nitride for densification and development of high toughness materials. The sintering aids used were designed to either form (1) rare earth silicates or (2) rare earth apatites as intergranular phases. MER was presently studying the effects on fracture toughness of (1) different starting $\alpha / \mathrm{B}-\mathrm{Si}_{3} \mathrm{~N}_{4}$ ratios and (2) additions of sintering aids as coatings (as compared to powders that are normally used). The samples were fabricated by hot-pressing or pressureless sintering.

This cooperative project was proposed as a joint development program between MER and Martin Marietta Energy Systems (MMES), the Contractor. Cooperative work was of benefit to both parties. ORNL was able to assess the properties of materials made with different starting $\alpha / \mathrm{B}-\mathrm{Si}_{3} \mathrm{~N}_{4}$ ratios and also examine the effects of the addition of sintering aids as coatings instead of powders. MER was able to gain access to GPS facilities and expertise for the densification and development of high toughness materials. Through the combination of efforts, silicon nitride ceramics with improved properties compared to current materials was anticipated.

\section{RESULTS}

The test matrix is shown in Tables 1 and 2. Materials with different starting $\alpha / B-S i_{3} \mathrm{~N}_{4}$ ratios and with the addition of sintering aids as coatings instead of powders were received from MER. Power batches were also made at ORNL with different starting $B-\mathrm{Si}_{3} \mathrm{~N}_{4}$ types and sizes.

The $\mathrm{B}-\mathrm{Si}_{3} \mathrm{~N}_{4}$ seed was produced by heating various combinations of $\mathrm{Si}_{3} \mathrm{~N}_{4}$ powders and $\mathrm{Y}_{2} \mathrm{O}_{3}$ as shown in Table 3. The powders were milled together and the fired at $1700^{\circ} \mathrm{C}$ for 4 hours to produce the B- phase materials. Scanning electron microscopy photographs of the B-phase powders are shown in Figs. 1 through 5. As shown, several different $\mathrm{B}-\mathrm{Si}_{3} \mathrm{~N}_{4}$ morphologies were produced. 
An initial set of samples were sintered by GPS using the optimum densification parameters developed for high toughness materials in the ORNL program. These densification results are summarized in Table 4. Additional samples were sintered by GPS using the same optimum densification parameters developed for high toughness materials in the ORNL program. These additional densification results are shown in Table 5.

As shown in Tables 4 and 5, high densities were achieved for all of the samples fabricated at ORNL and containing up to $50 \% \mathrm{~B}_{-} \mathrm{Si}_{3} \mathrm{~N}_{4}$. The lowest densities were observed for samples containing the Shin-etsu $\mathrm{B}-\mathrm{Si}_{3} \mathrm{~N}_{4}$ and the material with the $\mathrm{Y}_{2} \mathrm{O}_{3}-\mathrm{SiO}_{2}$ plus the B$\mathrm{Si}_{3} \mathrm{~N}_{4}$. The materials from MER containing the $B-\mathrm{Si}_{3} \mathrm{~N}_{4}$ powder from Shin-etsu also showed low densities.

The samples that achieved densities $>90 \%$ were machined into test bars for mechanical property testing as summarized in Table 6. As shown, a wide range of strengths and fracture toughness were obtained.

The effect of the type of $\mathrm{B}-\mathrm{Si}_{3} \mathrm{~N}_{4}$ seed on flexural strength and fracture toughness are illustrated in Fig. 6. The seeds fabricated by the reaction of either yttrium nitrate or $\mathrm{Y}_{2} \mathrm{O}_{3}$ powder and Ube E-10 $\mathrm{Si}_{3} \mathrm{~N}_{4}$ developed materials with the highest flexural strength. However, the fracture toughness of these materials (at the $25 \%$ addition level) showed no improvement over the baseline composition having no B-seed addition. High observed fracture toughness are usually associated with bimodal microstructures of high aspect ratio grains. The $B$-seeds made with Ube $\mathrm{E} 10 \mathrm{Si}_{3} \mathrm{~N}_{4}$ were similar in size to the $\alpha$-phase powder and during the initial stage liquid formation these seeds may have had dissolution rates similar or higher than the $\alpha$-phase powder. In that case, the $\beta$-seeds would have a minor contribution to the $\beta$-nucleation and result in the development of a uniform grain size. This may explain the improved strengths with no increase in toughness, but microstructure analysis will be done to confirm this.

In contrast, the $\mathrm{B}$-seeds made with the Ube $\mathrm{E} 03$ or Starck $\mathrm{S} 1 \mathrm{Si}_{3} \mathrm{~N}_{4}$ (and $\mathrm{Y}_{2} \mathrm{O}_{3}$ powder) were generally larger than the starting $\alpha$-phase powder. This resulted in materials with similar or slightly lower strengths, but significantly higher fracture toughness as shown in Fig. 6. The microstructures are believed to be more bimodal in grain size which would result in the increased fracture toughness. In the case of the samples made with the B-seed from Shin-Etsu, the low strengths are attributable to the poor densification exhibited by these materials. The higher toughness is probably due to a combination of some large $B$ $\mathrm{Si}_{3} \mathrm{~N}_{4}$ particles in the powder and the low density.

The effects of the $B$-seed content on flexural strength and fracture toughness are summarized in Fig. 7. As indicated, improvements in strength were observed with the addition of $25 \% \mathrm{~B}$-seed. At the other two additive levels (5 and $50 \%$ ) generally lower strengths were obtained, however, the results were mixed. The fracture toughness also showed no definite trend. Higher toughnesses were observed with $50 \%$ B-seed additions, while the other additive levels showed no consistent improvements.

\section{SUMMARY}

The Cooperative Research and Development Agreement (CRADA) with Materials and Electrochemical Research Corp. (MER) examined materials made with different starting $\alpha / B-S_{3} N_{4}$ ratios and with the addition of sintering aids as coatings instead of powders. The samples were sintered by GPS using optimum densification parameters developed for high toughness materials in the ORNL program. 
High densities were achieved for all of the samples fabricated at ORNL and containing up to $50 \% \mathrm{~B}_{-} \mathrm{Si}_{3} \mathrm{~N}_{4}$. The lowest densities were observed for samples containing the Shin-etsu $\mathrm{B}-\mathrm{Si}_{3} \mathrm{~N}_{4}$ and the material with the $\mathrm{Y}_{2} \mathrm{O}_{3}-\mathrm{SiO}_{2}$ plus the $\mathrm{B}-\mathrm{Si}_{3} \mathrm{~N}_{4}$. The materials from MER containing the $\mathrm{B}-\mathrm{Si}_{3} \mathrm{~N}_{4}$ powder from Shin-etsu also showed low densities.

The addition of the sintering aids by using coatings resulted in lower strengths as compared to powder additions for all sintering aid types. The effect of coatings on the fracture toughness generally showed decreased values with the exception of the $\mathrm{Y}_{2} \mathrm{O}_{3}-\mathrm{Al}_{2} \mathrm{O}_{3}$ system.

The effect of the type of $B-\mathrm{Si}_{3} \mathrm{~N}_{4}$ seed on flexural strength and fracture toughness indicated seeds fabricated by the reaction of either ytrium nitrate or $\mathrm{Y}_{2} \mathrm{O}_{3}$ powder and Ube E-10 $\mathrm{Si}_{3} \mathrm{~N}_{4}$ developed materials with the highest flexural strength. However, the fracture toughness of these materials (at the $25 \%$ addition level) showed no improvement over the baseline composition having no $B$-seed addition.

The effects of the B-seed content on flexural strength and fracture toughness were mixed. Higher toughnesses were observed with $50 \%$ B-seed additions, while the other additive levels showed no consistent improvements. The seed material fabricated from Ube E-03 powder exhibited the highest improvement in fracture toughness. 
Table 1. Test matrix to determine effects of $\mathrm{B}-\mathrm{Si}_{3} \mathrm{~N}_{4}$ Content and type for samples fabricated at ORNL.

\begin{tabular}{|c|c|c|c|c|}
\hline $\begin{array}{l}\text { Test } \\
\text { No. }\end{array}$ & Grain Boundary Phase Composition & $\begin{array}{l}\text { Rare Earth } \\
\text { Addition }\end{array}$ & $\begin{array}{c}\mathrm{B}-\mathrm{Si}_{3} \mathrm{~N}_{4} \\
\text { Content }(\%)\end{array}$ & $\begin{array}{c}{\mathrm{B}-\mathrm{Si}_{3} \mathrm{~N}_{4}} \\
\text { Seed Source }\end{array}$ \\
\hline$\overline{\mathrm{MR}-1}$ & 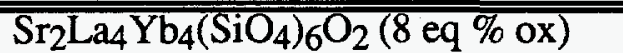 & Powder & 0 & \\
\hline MR-2 & $\mathrm{Sr}_{2} \mathrm{La}_{4} \mathrm{Yb}_{4}\left(\mathrm{SiO}_{4}\right)_{6} \mathrm{O}_{2}(8 \mathrm{eq} \%$ ox $)$ & Powder & 25 & ORNL\#1 \\
\hline MR-3 & $\mathrm{Sr}_{2} \mathrm{La}_{4} \mathrm{Yb}_{4}\left(\mathrm{SiO}_{4}\right)_{6} \mathrm{O}_{2}(8 \mathrm{eq} \%$ ox $)$ & Powder & 25 & ORNL \#2 \\
\hline MR-4 & $\mathrm{Sr}_{2} \mathrm{La}_{4} \mathrm{Yb}_{4}\left(\mathrm{SiO}_{4}\right)_{6} \mathrm{O}_{2}(8$ eq $\%$ ox $)$ & Powder & 25 & ORNL \#3 \\
\hline MR-5 & $\mathrm{Sr}_{2} \mathrm{La}_{4} \mathrm{Yb}_{4}\left(\mathrm{SiO}_{4}\right)_{6} \mathrm{O}_{2}(8$ eq \% ox $)$ & Powder & 25 & ORNL \#4 \\
\hline MR-6 & $\mathrm{Sr}_{2} \mathrm{La}_{4} \mathrm{Yb}_{4}\left(\mathrm{SiO}_{4}\right)_{6} \mathrm{O}_{2}$ (8 eq \% ox) & Powder & 25 & Shin-Etsu \\
\hline MR-7 & $\mathrm{Sr}_{2} \mathrm{La}_{4} \mathrm{Yb}_{4}\left(\mathrm{SiO}_{4}\right)_{6} \mathrm{O}_{2}(8 \mathrm{eq} \%$ ox $)$ & Powder & 50 & ORNL \#1 \\
\hline MR-8 & $\mathrm{Sr}_{2} \mathrm{La}_{4} \mathrm{Yb}_{4}\left(\mathrm{SiO}_{4}\right)_{6} \mathrm{O}_{2}$ (8 eq \% ox) & Powder & 5 & ORNL \#1 \\
\hline MR-9 & $\mathrm{Y}_{2} \mathrm{Si}_{2} \mathrm{O}_{7}$ (5 eq. \% ox.) & Powder & 0 & \\
\hline MR-10 & $\mathrm{Y}_{2} \mathrm{Si}_{2} \mathrm{O}_{7}$ (5 eq. \% ox.) & Powder & 25 & ORNL \#1 \\
\hline & $\mathrm{Sr}_{2} \mathrm{La}$ & Powder & 50 & ORNL \#2 \\
\hline MR-12 & $\mathrm{Sr}_{2} \mathrm{La}_{4} \mathrm{Yb}_{4}\left(\mathrm{SiO}_{4}\right)_{6} \mathrm{O}_{2}$ & Powder & 5 & ORNL\#2 \\
\hline
\end{tabular}

Table 2. Test matrix to determine effects of $\mathrm{B}-\mathrm{Si}_{3} \mathrm{~N}_{4}$ content and rare addition method for samples fabricated at MER.

\begin{tabular}{lllcc}
\hline $\begin{array}{l}\text { Test } \\
\text { No. }\end{array}$ & Composition & $\begin{array}{l}\text { Rare Earth } \\
\text { Addition }\end{array}$ & $\begin{array}{c}\mathrm{B}-\mathrm{Si}_{3} \mathrm{~N}_{4} \\
\text { Content }(\%)\end{array}$ & $\begin{array}{c}\mathrm{B}-\mathrm{Si}_{3} \mathrm{~N}_{4} \\
\text { Seed Source }\end{array}$ \\
\hline \hline $\mathrm{MC}-1$ & $4 \% \mathrm{Nd}_{2} \mathrm{O}_{3}-1 \% \mathrm{Al}_{2} \mathrm{O}_{3}$ & Powder & 0 & -- \\
$\mathrm{MC}-2$ & $4 \% \mathrm{Nd}_{2} \mathrm{O}_{3}-1 \% \mathrm{Al}_{2} \mathrm{O}_{3}$ & Coating & 0 & -- \\
$\mathrm{MC}-3$ & $4 \% \mathrm{Nd}_{2} \mathrm{O}_{3}-1 \% \mathrm{Al}_{2} \mathrm{O}_{3}$ & Coating & 25 & Shin-Etsu \\
$\mathrm{MC}-4$ & $4 \% \mathrm{Nd}_{2} \mathrm{O}_{3}-1 \% \mathrm{Al}_{2} \mathrm{O}_{3}$ & Coating & 50 & Shin-Etsu \\
$\mathrm{MC}-5$ & $4 \% \mathrm{Nd}_{2} \mathrm{O}_{3}-1 \% \mathrm{Al}_{2} \mathrm{O}_{3}$ & Coating & 5 & Shin-Etsu \\
& & & & \\
$\mathrm{MC}-6$ & $4 \% \mathrm{Y}_{2} \mathrm{O}_{3}-1 \% \mathrm{Al}_{2} \mathrm{O}_{3}$ & Powder & 0 & -- \\
$\mathrm{MC}-7$ & $4 \% \mathrm{Y}_{2} \mathrm{O}_{3}-1 \% \mathrm{Al}_{2} \mathrm{O}_{3}$ & Coating & 0 & - \\
$\mathrm{MC}-8$ & $\mathrm{Y}_{2} \mathrm{Si}_{2} \mathrm{O}_{7}(5$ eq. $\%$ ox.) & Powder & 0 & -- \\
$\mathrm{MC}-9$ & $\mathrm{Y}_{2} \mathrm{Si}_{2} \mathrm{O}_{7}$ (5 eq. \% ox.) & Coating & 0 & -- \\
$\mathrm{MC}-10$ & $\mathrm{Y}_{2} \mathrm{Si}_{2} \mathrm{O}_{7}$ (5 eq. \% ox.) & Coating & 25 & Shin-Etsu \\
\hline
\end{tabular}

Table 3. Fabrication of $\mathrm{B}_{-} \mathrm{Si}_{3} \mathrm{~N}_{4}$ seed at ORNL.

\begin{tabular}{lllc}
\hline $\mathrm{B}-\mathrm{Si}_{3} \mathrm{~N}_{4}$ Seed & $\mathrm{Starting} \mathrm{Si}_{3} \mathrm{~N}_{4}$ & $\mathrm{Y}_{2} \mathrm{O}_{3}$ Addition & $\mathrm{B}_{-} \mathrm{Si}_{3} \mathrm{~N}_{4}$ Content (\%) \\
Fabrication Number & Powder & & \\
\hline \hline ORNL \#1 & Ube E-10 & 0.7 wt.\% (as nitrate) & 93 \\
ORNL \#2 & Ube E-10 & 1 wt.\% (powder) & 100 \\
ORNL \#3 & Ube E-03 & 1 wt.\% (powder) & 78 \\
ORNL \#4 & Starck S1 & 1 wt.\% (powder) & 100 \\
\hline
\end{tabular}


Table 4. Summary of results on densification of samples from CRADA with MER Corp.

\begin{tabular}{lccc}
\hline Sample No. & $\begin{array}{c}\text { Weight Loss } \\
(\%)\end{array}$ & $\begin{array}{c}\text { Density } \\
\left(\mathrm{g} / \mathrm{cm}^{3}\right)\end{array}$ & $\begin{array}{c}\text { Density } \\
(\% \text { T. D. })\end{array}$ \\
\hline \hline MR-1 & 3.4 & 3.46 & 98.2 \\
MR-2 & 2.5 & 3.49 & 99.0 \\
MR-3 & 2.9 & 3.51 & 99.6 \\
MR-4 & 3.5 & 3.43 & 97.4 \\
MR-5 & 0.2 & 3.44 & 97.6 \\
MR-6 & 3.9 & 3.12 & 88.6 \\
MR-7 & 2.3 & 3.38 & 96.1 \\
MR-8 & 3.2 & 3.40 & 96.5 \\
MR-9 & 1.7 & 3.11 & 92.9 \\
MR-10 & 2.5 & 2.90 & 86.5 \\
MR-11 & 5.5 & 3.58 & 101.6 \\
MR-12 & 3.8 & 3.48 & 98.9 \\
& & & \\
MC-1 & 2.3 & 3.20 & 97.7 \\
MC-2 & 2.6 & 3.14 & 95.6 \\
MC-3 & 4.9 & 2.89 & 88.1 \\
MC-4 & 5.5 & 2.59 & 79.1 \\
MC-5 & 3.8 & 3.21 & 97.9 \\
MC-6 & 2.3 & 3.12 & 95.9 \\
MC-7 & 3.6 & 3.03 & 93.1 \\
MC-8 & 2.3 & 3.34 & 99.6 \\
MC-9 & 5.2 & 2.52 & 75.1 \\
MC-10 & 4.9 & 3.13 & 93.3 \\
\hline
\end{tabular}


Table 5. Summary of results on densification of samples from CRADA with MER Corp. gas pressure sintered at $1900^{\circ} \mathrm{C} / 1950^{\circ} \mathrm{C}$.

\begin{tabular}{lccc}
\hline Sample No. & $\begin{array}{c}\text { Weight Loss } \\
(\%)\end{array}$ & $\begin{array}{c}\text { Density } \\
\left(\mathrm{g} / \mathrm{cm}^{3}\right)\end{array}$ & $\begin{array}{c}\text { Density } \\
(\% \text { T. D.) }\end{array}$ \\
\hline \hline MR-1 & 5.4 & 3.50 & 99.5 \\
MR-2 & 4.5 & 3.53 & 100.3 \\
MR-3 & 4.1 & 3.54 & 100.5 \\
MR-4 & 4.3 & 3.53 & 100.4 \\
MR-5 & 3.7 & 3.54 & 100.5 \\
MR-6 & 4.3 & 3.31 & 94.0 \\
MR-7 & 2.7 & 3.52 & 99.9 \\
MR-8 & 3.4 & 3.51 & 99.6 \\
MR-9 & 1.3 & 3.22 & 96.1 \\
MR-10 & 2.0 & 3.11 & 92.9 \\
MR-11 & 4.8 & 3.52 & 100.0 \\
MR-12 & 4.2 & 3.50 & 99.4 \\
& & & \\
MC-1 & 3.4 & 3.22 & 98.1 \\
MC-2 & 2.4 & 3.22 & 98.3 \\
MC-3 & 4.2 & 2.81 & 85.7 \\
MC-4 & 4.5 & 2.66 & 81.2 \\
MC-5 & 1.1 & 3.18 & 97.0 \\
MC-6 & 1.1 & 3.18 & 97.9 \\
MC-7 & 1.6 & 3.15 & 97.0 \\
MC-8 & 0.6 & 3.23 & 96.4 \\
MC-9 & 2.5 & 3.05 & 91.0 \\
MC-10 & 2.1 & 3.16 & 94.4 \\
\hline
\end{tabular}


Table 6. Summary of results on densification of samples from CRADA with MER Corp. gas pressure sintered at $1900^{\circ} \mathrm{C} / 1950^{\circ} \mathrm{C}$.

\begin{tabular}{lcccc}
\hline Sample No. & $\begin{array}{c}\text { Density } \\
\left(\mathrm{g} / \mathrm{cm}^{3}\right)\end{array}$ & $\begin{array}{c}\text { Density } \\
(\% \text { T. D.) }\end{array}$ & $\begin{array}{c}\text { Flexural } \\
\text { Strength (MPa) }\end{array}$ & $\begin{array}{c}\text { Fracture } \\
\text { Toughness, } \\
(\mathrm{MPa} \text { Im) }\end{array}$ \\
\hline \hline MR-1 & 3.50 & 99.5 & 646 & 6.6 \\
MR-2 & 3.53 & 100.3 & 721 & 6.4 \\
MR-3 & 3.54 & 100.5 & 704 & 6.3 \\
MR-4 & 3.53 & 100.4 & 665 & 8.2 \\
MR-5 & 3.54 & 100.5 & 498 & 7.9 \\
MR-6 & 3.31 & 94.0 & 359 & 7.7 \\
MR-7 & 3.52 & 99.9 & 425 & 7.7 \\
MR-8 & 3.51 & 99.6 & 514 & 8.7 \\
MR-9 & 3.22 & 96.1 & 550 & 6.9 \\
MR-10 & 3.11 & 92.9 & 464 & 9.0 \\
MR-11 & 3.52 & 100.0 & 682 & 8.1 \\
MR-12 & 3.50 & 99.4 & 616 & 5.6 \\
& & & & \\
MC-1 & 3.22 & 98.1 & 627 & 8.5 \\
MC-2 & 3.22 & 98.3 & 529 & 5.5 \\
MC-3 & 2.81 & 85.7 & -- & -- \\
MC-4 & 2.66 & 81.2 & -- & - \\
MC-5 & 3.18 & 97.0 & 669 & 6.1 \\
MC-6 & 3.18 & 97.9 & 651 & 5.9 \\
MC-7 & 3.15 & 97.0 & 348 & 6.2 \\
MC-8 & 3.23 & 96.4 & 562 & 6.4 \\
MC-9 & 3.05 & 91.0 & 508 & 6.3 \\
MC-10 & 3.16 & 94.4 & 540 & 5.7 \\
\hline
\end{tabular}




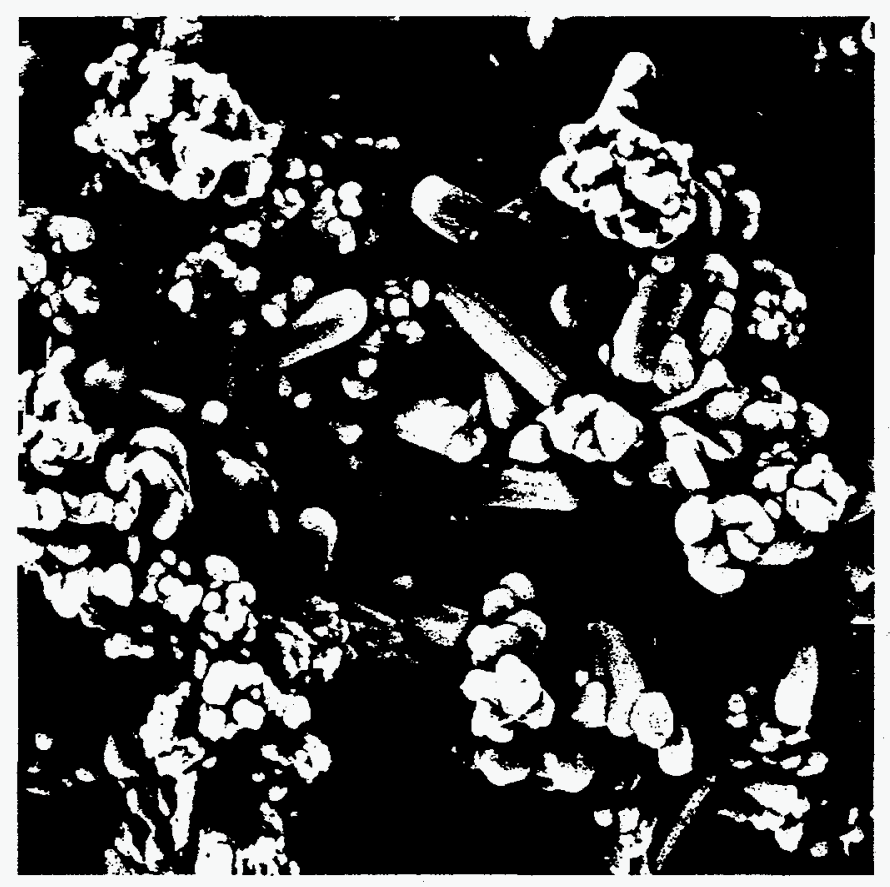

Fig. 1. SEM of $\mathrm{B}_{-} \mathrm{Si}_{3} \mathrm{~N}_{4}$ seed material E10/Nit.

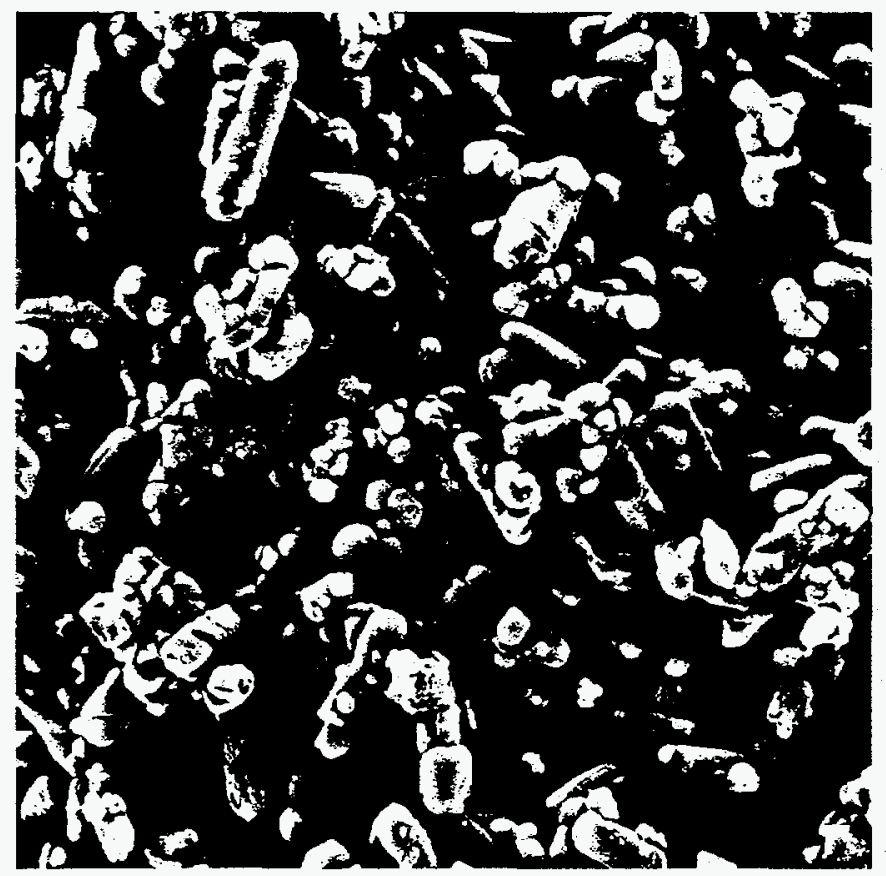

Fig. 2. SEM of $B-\mathrm{Si}_{3} \mathrm{~N}_{4}$ seed material E10/Pwd. 


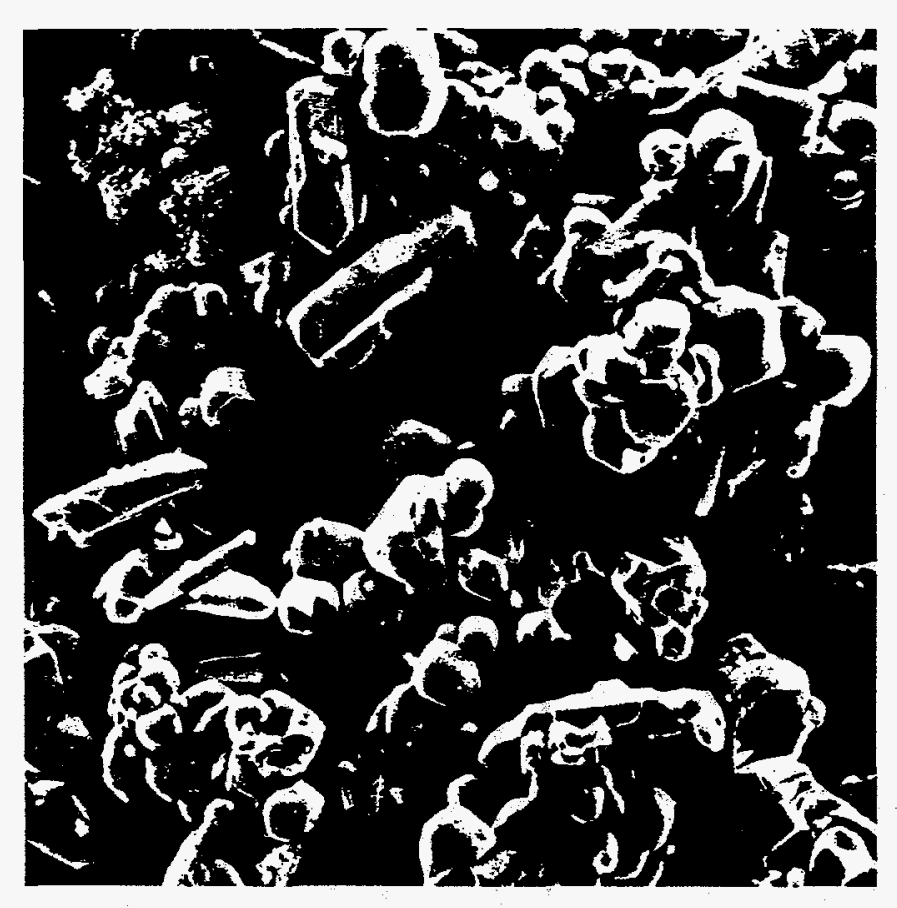

Fig. 3. SEM of $\mathrm{B}-\mathrm{Si}_{3} \mathrm{~N}_{4}$ seed material E3/Pwd.

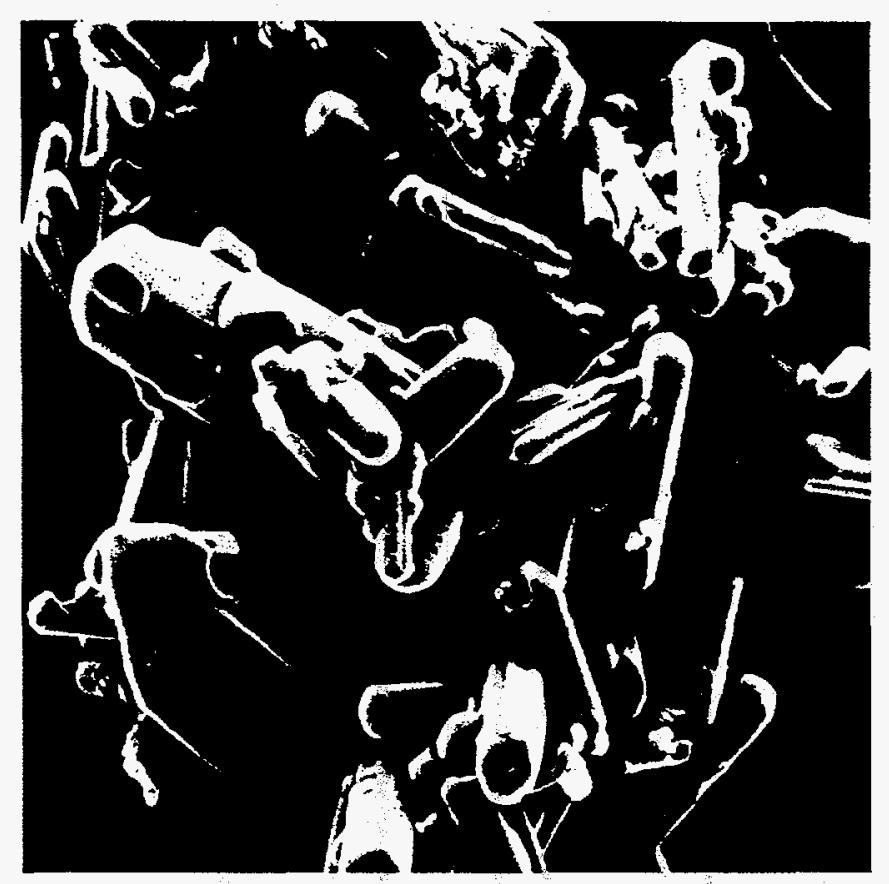

Fig. 4. SEM of $B-\mathrm{Si}_{3} \mathrm{~N}_{4}$ seed material S1/Pwd. 


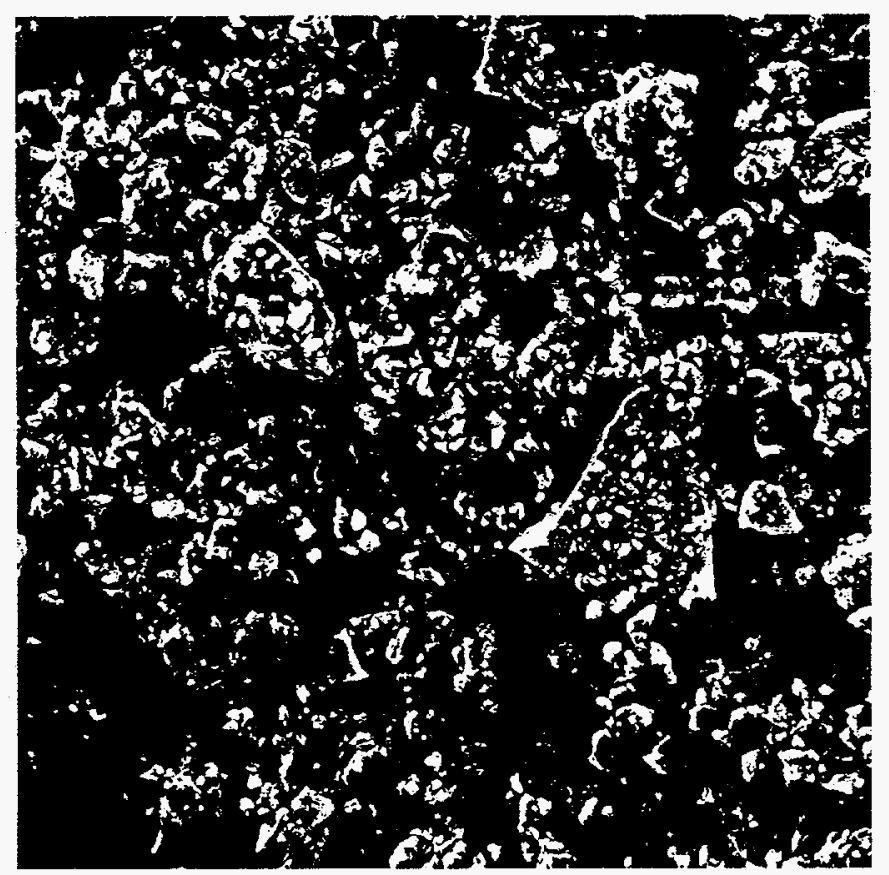

Fig. 5. SEM of $B-\mathrm{Si}_{3} \mathrm{~N}_{4}$ seed material Shin-etsu. 


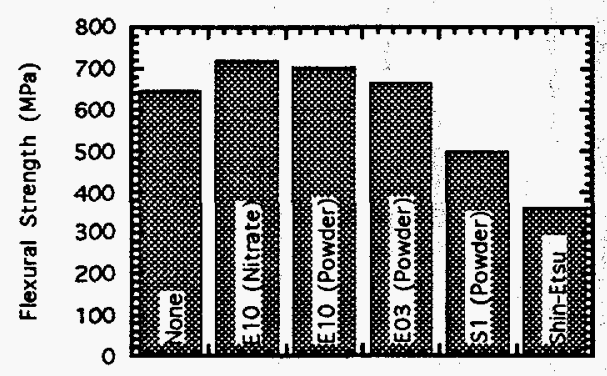

(a)

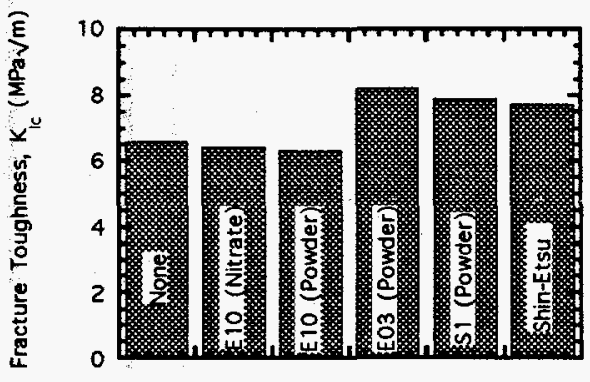

(b)

Fig. 6. Effect of $B$-seed type on the (a) flexural strength and (b) fracture toughness for gaspressure sintered silicon nitride with $\mathrm{Si}_{3} \mathrm{~N}_{4}-\mathrm{Sr}_{2} \mathrm{La}_{4} \mathrm{Yb}_{4}\left(\mathrm{SiO}_{4}\right)_{6} \mathrm{O}_{2}$ composition.

(a)

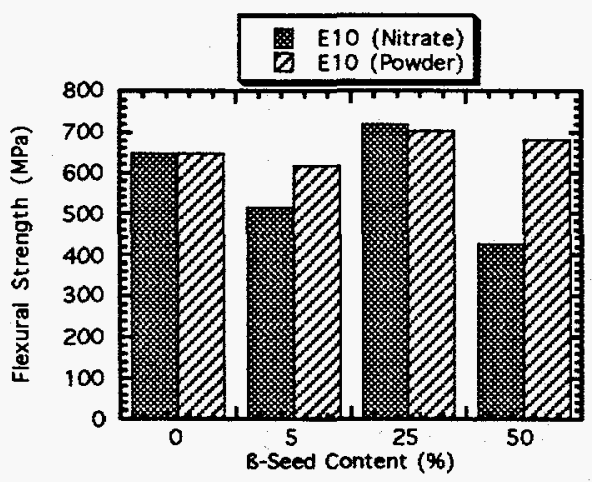

(b)

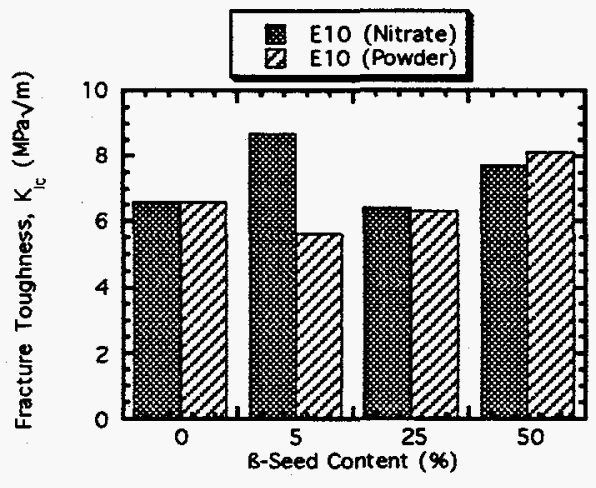

Fig. 7. Effect of $B$-seed content on the (a) flexural strength and (b) fracture toughness for gas-pressure sintered silicon nitride with $\mathrm{Si}_{3} \mathrm{~N}_{4}-\mathrm{Sr}_{2} \mathrm{La}_{4} \mathrm{Yb}_{4}\left(\mathrm{SiO}_{4}\right)_{6} \mathrm{O}_{2}$ composition. 


\section{DISTRIBUTION}

1. Robert B. Schulz, Office of Heavy Vehicle Technologies, DOE, EE-33, 1000 Independence Avenue, S.W., Washington, D.C. 20585

2-3. Office of Scientific and Techical Information, P. O. Box 62, Oak Ridge, TN 37831

4. Work for Others Office, DOE-ORO, ER-113, P. O. Box 2001, Oak Ridge, TN 37831

5. P. L. Gorman, DOE-ORO, ORNL Site Office, P. O. Box 2008, Oak Ridge, TN 37831-6269

6. Materials and Electrochemical Research Corporation, 7960 South Kolb Road, Tucson, AZ 85706

7. R. A. Bradley

8. D. F. Craig

9. R. G. Gilliland

10. D. R. Hamrin

11. D. R. Johnson

12. R. J. Lauf

13. A. J. Luffman

14. A. C. Schaffhauser

15-24. T. N. Tiegs

25. C. A. Valentine 